This item was submitted to Loughborough's Research Repository by the author.

Items in Figshare are protected by copyright, with all rights reserved, unless otherwise indicated.

\title{
In situ observation of the $\mathrm{pH}$ gradient near the gas diffusion electrode of $\mathrm{CO} 2$ reduction in alkaline electrolyte
}

PLEASE CITE THE PUBLISHED VERSION

https://doi.org/10.1021/jacs.0c06779

\section{PUBLISHER}

American Chemical Society (ACS)

\section{VERSION}

AM (Accepted Manuscript)

\section{PUBLISHER STATEMENT}

This document is the Accepted Manuscript version of a Published Work that appeared in final form in Journal of the American Chemical Society, copyright @ American Chemical Society after peer review and technical editing by the publisher. To access the final edited and published work see https://doi.org/10.1021/jacs.0c06779

\section{LICENCE}

CC BY-NC-ND 4.0

\section{REPOSITORY RECORD}

Lu, Xu, Chongqin Zhu, Zishan Wu, Jin Xuan, Joseph S Francisco, and Hailiang Wang. 2020. "In Situ Observation of the Ph Gradient Near the Gas Diffusion Electrode of CO2 Reduction in Alkaline Electrolyte". Loughborough University. https://hdl.handle.net/2134/13095641.v1. 


\title{
In-Situ Observation of the pH Gradient near the Gas Diffusion Electrode of $\mathrm{CO}_{2}$ Reduction in
}

\section{Alkaline Electrolyte}

\author{
$\mathrm{Xu} \mathrm{Lu}{ }^{1,2}$, Chongqin $\mathrm{Zhu}^{3}$, Zishan $\mathrm{Wu}^{1,2}$, Jin Xuan ${ }^{4}$, Joseph S. Francisco ${ }^{3 *} \&$ Hailiang Wang ${ }^{1,2^{*}}$ \\ ${ }^{1}$ Department of Chemistry, Yale University, New Haven, Connecticut 06520, United States \\ ${ }^{2}$ Energy Sciences Institute, Yale University, West Haven, Connecticut 06516, United States \\ 3 Department of Earth and Environmental Science and Department of Chemistry, University of \\ Pennsylvania, Philadelphia, Pennsylvania 19104, United States \\ ${ }^{4}$ Department of Chemical Engineering, Loughborough University, Loughborough, United Kingdom \\ * Corresponding author: Prof. Hailiang Wang (E-mail: hailiang.wang@yale.edu), Prof. Joseph Francisco \\ (E-mail: frjoseph@sas.upenn.edu)
}

\begin{abstract}
The local $\mathrm{pH}$ variation near the surface of $\mathrm{CO}_{2}$ reduction electrodes is important but hard to study. We develop a continuous-flow Raman electrochemical cell that enables the first experimental study of the local $\mathrm{pH}$ near a $\mathrm{CO}_{2}$ reduction gas diffusion electrode under reaction conditions. At zero current, $\mathrm{CO}_{2}$ chemically reacts with the $1 \mathrm{M} \mathrm{KOH}$ electrolyte at the interface to form $\mathrm{HCO}_{3}{ }^{-}$and $\mathrm{CO}_{3}{ }^{2-}$. The local $\mathrm{pH}$ on the cathode surface is 7.2 and the $\mathrm{HCO}_{3}{ }^{-}$concentration profile extends a distance of $120 \mu \mathrm{m}$ into the electrolyte, which verifies that the nominal overpotential reduction from using alkaline electrolyte originates from the Nernst potential of the $\mathrm{pH}$ gradient layer at the cathode/electrolyte interface. The $\mathrm{CO}_{2}-\mathrm{OH}^{-}$neutralization reaction and the $\mathrm{pH}$ gradient layer still persist, albeit to a reduced extent, at $\mathrm{CO}_{2}$ reduction current densities up to $150 \mathrm{~mA} / \mathrm{cm}^{2}$.
\end{abstract}




\section{Introduction}

$\mathrm{CO}_{2}$ electroreduction reactions are promising for producing fuels and chemicals from cheap and abundant $\mathrm{CO}_{2}$ resources using renewable electricity. Electrochemical conversion of $\mathrm{CO}_{2}$ to $\mathrm{CO},{ }^{1-5}$ formic acid, ${ }^{6-7}$ hydrocarbons ${ }^{8-11}$ or alcohols, ${ }^{12-14}$ allows storing renewable energy in fuels, and provides useful chemicals. Conventional three-electrode cells, ${ }^{15}$ where the reaction is performed using $\mathrm{CO}_{2}$ dissolved in the electrolyte, are well-defined for studying electrocatalytic properties of materials. However, the relatively low concentration and sluggish diffusion of $\mathrm{CO}_{2}$ in the solution phase make it difficult to reach applicationrelevant high current densities $\left(>0.1\right.$ or even $\left.1 \mathrm{~A} / \mathrm{cm}^{2}\right)$. Employing gas diffusion electrodes (GDEs) ${ }^{16}$ in flow electrolyzers can greatly enhance the mass transport of $\mathrm{CO}_{2}$ by forming a gas-liquid-solid three-phase interface and hence substantially increase the diffusion-limited current density. ${ }^{13,17}$ While common $\mathrm{CO}_{2}$ electrolytic cells often use near-neutral aqueous solutions such as $\mathrm{KHCO}_{3}$ as the electrolyte, ${ }^{18-20}$ adopting alkaline electrolyte solutions are found to significantly lower the overpotential for $\mathrm{CO}_{2}$ reduction. ${ }^{1,3-5,11,14}$ Current densities greater than $1 \mathrm{~A} / \mathrm{cm}^{2}$ have also been achieved with alkaline electrolytes. ${ }^{21-22}$ Despite the improved performance, there is controversy regarding its origin. Some studies attribute this to a simple $\mathrm{pH}$ effect assuming the catalyst works in the same alkaline environment as the bulk electrolyte (Figure 1a). ${ }^{5,22}$ However, this hypothesis neglects the chemical reaction between $\mathrm{CO}_{2}$ and $\mathrm{OH}^{-}$and cannot justify the same magnitude of overpotential reduction experimentally observed for the $\mathrm{CO}_{2}$-to- $\mathrm{CO}$ conversion (2-electron 2-proton process) catalyzed by $\mathrm{Au}$ and the $\mathrm{CO}_{2}$-to-formate conversion (2-electron 1-proton process) catalyzed by $\mathrm{SnO}_{2}$ (both $\sim 60 \mathrm{mV} / \mathrm{pH}$ ). ${ }^{1}$ We therefore postulated that the local environment at the cathode surface is near neutral because of the $\mathrm{CO}_{2}-\mathrm{OH}^{-}$neutralization reaction (Figure $1 \mathrm{~b}$ ), and the $\mathrm{pH}$ gradient across the cathode and the bulk alkaline electrolyte creates a Nernst potential. ${ }^{1}$ This can readily explain the voltage improvement observed for all our alkaline $\mathrm{CO}_{2}$ electrolyzers using different cathode catalysts for different products and is supported by the observation that the electrolyte is indeed gradually neutralized under continuous working conditions. ${ }^{1}$

To further consolidate this postulation, it is necessary to probe the local $\mathrm{pH}$ near the $\mathrm{CO}_{2}$-reduction GDE in a flow electrolyzer under reaction conditions, which has not been experimentally demonstrated to date. In addition to mathematic models and simulations, ${ }^{11,23}$ possible experimental methods to study the local $\mathrm{pH}$ include $\mathrm{pH}$-sensitive microelectrodes, rotating disk electrode (RDE) measurements, and spectroscopic tools. Microelectrodes need to be positioned near the catalytic electrode surface, and thus inevitably invade the local environment and disrupt the species fluxes there. ${ }^{24-27} \mathrm{RDE}$ experiments could circumvent this issue and measure the electrode surface $\mathrm{pH}$ during hydrogen oxidation/evolution reactions, ${ }^{28-29}$ but whether this method would be applicable to $\mathrm{CO}_{2}$ reduction reactions is not clear. Non-destructive Raman or IR spectroscopy could directly probe $\mathrm{pH}$-sensitive electrolyte species such as carbonate $\left(\mathrm{CO}_{3}{ }^{2-}\right)$ and 
bicarbonate $\left(\mathrm{HCO}_{3}^{-}\right)$at the electrode/electrolyte interface, but almost all these studies are conducted on gas-impermeable electrodes, some of which require the catalyst to be coated on a prism and hence are not even compatible with the GDE and flow cell configuration. ${ }^{30-33}$

\section{Results and Discussion}

Herein, we report the design of an alkaline $\mathrm{CO}_{2}$ electrolyzer that allows in-situ Raman microscopy to be performed under continuous flow and reaction conditions to unveil the $\mathrm{pH}$ variation from the cathodic GDE surface to the electrolyte bulk. Micro-area Raman spectra are recorded to analyze the concentrations of $\mathrm{HCO}_{3}{ }^{-}$and $\mathrm{CO}_{3}{ }^{2-}$ as functions of the distance from the electrode surface into the electrolyte bulk, which are extrapolated to the cathode surface assuming steady-state concentrations and acid-base equilibria. The $\mathrm{pH}$ values are then derived from the concentrations and equilibrium constants. With $1 \mathrm{M} \mathrm{KOH}$ as the electrolyte, we find that under open-circuit conditions the local environment at the cathode surface is near neutral and the $\mathrm{pH}$ increases to $>11$ over a distance of $120 \mu \mathrm{m}$ into the electrolyte, which is attributed to the $\mathrm{CO}_{2}-\mathrm{OH}^{-}$neutralization reaction. Applying a reduction current raises the $\mathrm{pH}$ near the cathode surface and narrows the $\mathrm{pH}$ gradient layer, largely due to the generation of $\mathrm{OH}^{-}$from the electrochemical $\mathrm{CO}_{2}$ reduction reaction. However, the generated $\mathrm{OH}^{-}$at current densities up to $150 \mathrm{~mA} / \mathrm{cm}^{2}$ can still not balance the consumption from the chemical reaction with $\mathrm{CO}_{2}$. These results confirm that the overpotential reduction of alkaline $\mathrm{CO}_{2}$ electrolyzers compared to neutral ones originates from the $\mathrm{pH}$ gradient at the cathode/electrolyte interface. 

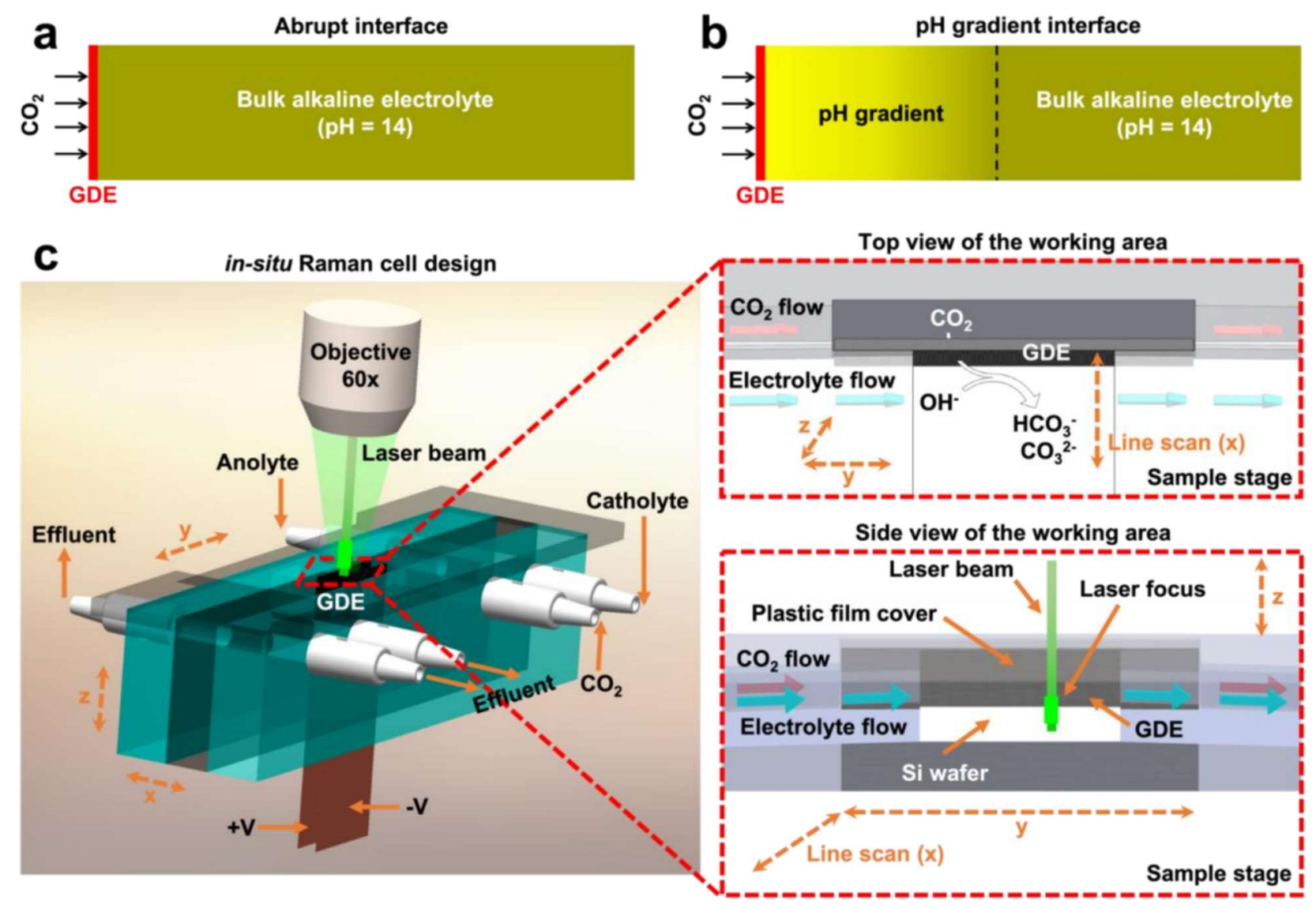

Figure 1. Designed flow cell for performing in-situ Raman measurements under continuous-flow $\mathrm{CO}_{2}$ reduction conditions to distinguish between (a) an abrupt interface and (b) a gradient interface between the cathode and electrolyte. (c) Cell design with top and side views of the cathode area.

We modified our previously developed flow electrolyzer ${ }^{1,18}$ to allow for examination using a confocal Raman microscope under reaction conditions (Figure 1c). In this configuration, the micron-size laser beam is parallel to the GDE surface which separates the $\mathrm{CO}_{2}$ gas and liquid electrolyte. The distance from the laser beam to the electrode surface is controlled by the mechanical sample stage for line scan measurements (Figure $1 \mathrm{c}$ top view). We chose $\mathrm{HCO}_{3}{ }^{-}$and $\mathrm{CO}_{3}{ }^{2-}$ as $\mathrm{pH}$ probes because: i) they are the products of the $\mathrm{CO}_{2}-\mathrm{OH}^{-}$neutralization reaction, which avoids any interference from incorporating additional $\mathrm{pH}$-sensitive species, ii) they have distinguishable Raman features and can be independently quantified using calibration curves (Figure S1), and iii) the acid-based equilibrium between them can be used to derive the $\mathrm{pH}$.

We first studied the system at open circuit with $1 \mathrm{M} \mathrm{KOH}$ electrolyte flowing at $0.5 \mathrm{~mL} / \mathrm{min}$ and $\mathrm{CO}_{2}$ flowing at $20 \mathrm{sccm}$. This zero-current scenario corresponds to situations when the cathode potential is more positive than the onset potential for $\mathrm{CO}_{2}$ reduction. As shown in Figure $2 \mathrm{a}, \mathrm{HCO}_{3}{ }^{-}$and $\mathrm{CO}_{3}{ }^{2-}$ peaks are recorded at $1012 \mathrm{~cm}^{-1}$ and $1064 \mathrm{~cm}^{-1}$, respectively, when the laser beam is positioned $10 \mu \mathrm{m}$ away from the 
cathode into the electrolyte $(\mathrm{x}=-10 \mu \mathrm{m}$, where $\mathrm{x}$ denotes the distance from the cathode surface and the negative sign indicates the direction from the cathode to the electrolyte). The existence of $\mathrm{HCO}_{3}{ }^{-}$and $\mathrm{CO}_{3}{ }^{2-}$ unambiguously proves that $\mathrm{CO}_{2}$ reacts with the alkaline electrolyte, at least when there is no net $\mathrm{CO}_{2}$ electroreduction. As the laser beam is moved further away from the GDE surface into the electrolyte, the detected $\mathrm{HCO}_{3}{ }^{-}$concentration decreased from $0.22 \mathrm{M}$ at x $=-10 \mu \mathrm{m}$ to $0.024 \mathrm{M}$ at $\mathrm{x}=-120 \mu \mathrm{m}$, and the $\mathrm{CO}_{3}{ }^{2-}$ concentration increased from $0.065 \mathrm{M}$ to $0.20 \mathrm{M}$ (Figure $2 \mathrm{~b}$ ). These trends indicate that the $\mathrm{HCO}_{3}{ }^{-}$ originates from the $\mathrm{CO}_{2}-\mathrm{OH}^{-}$neutralization at the cathode/electrolyte interface and diffuses into the $\mathrm{KOH}$ electrolyte where it is further deprotonated to form $\mathrm{CO}_{3}{ }^{2-}$.

a

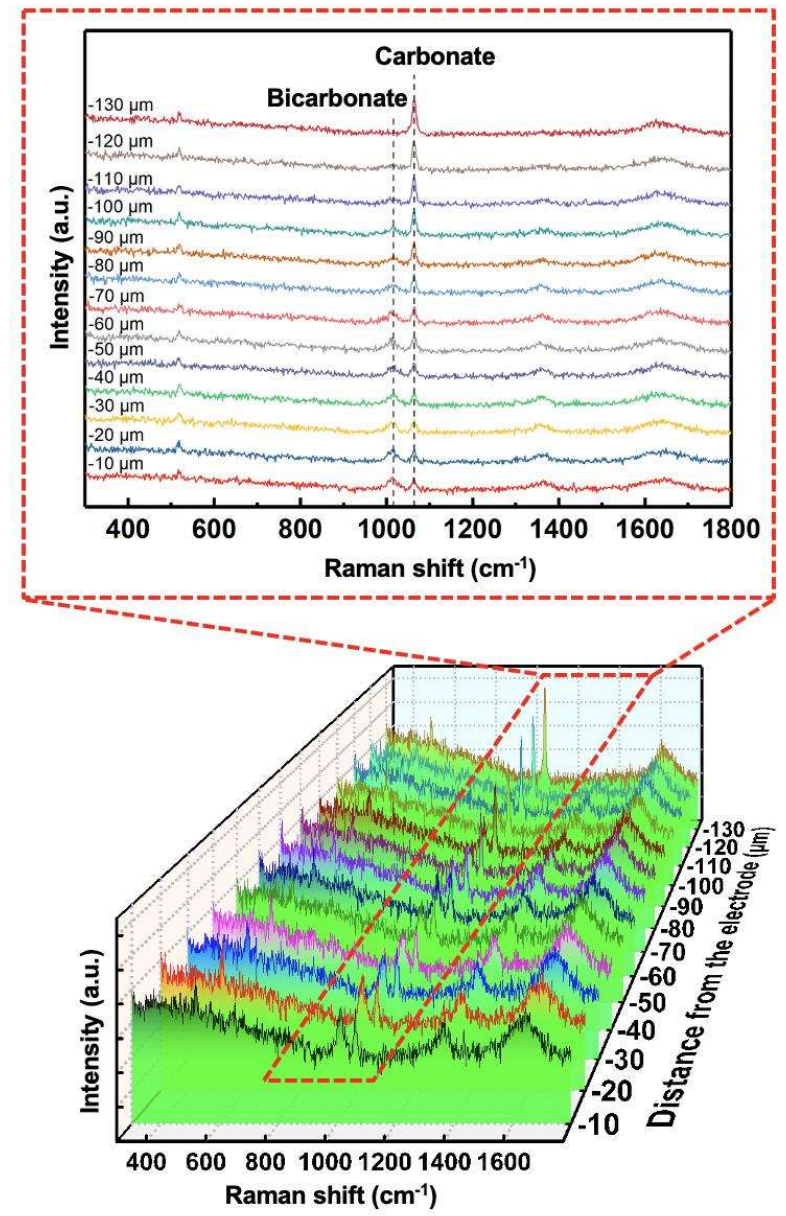

b

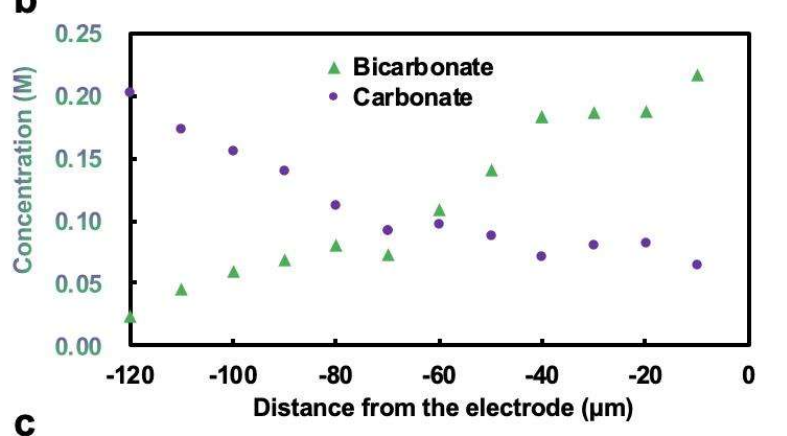

c
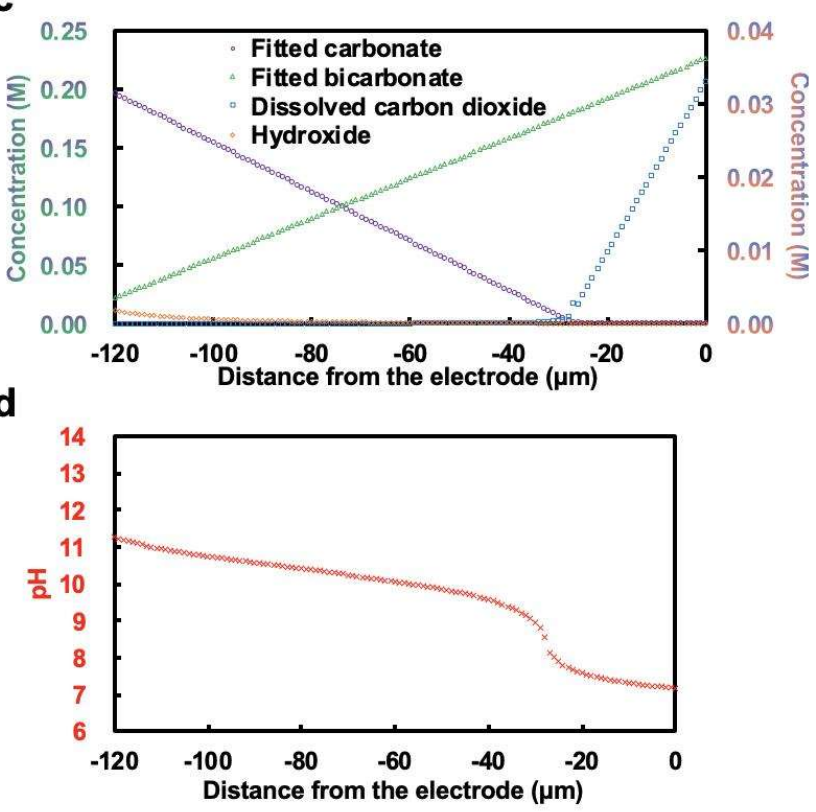

Figure 2. (a) Raman spectra recorded at various distances from GDE surface. Current density: $0 \mathrm{~mA} / \mathrm{cm}^{2}$. Electrolyte: $1 \mathrm{M} \mathrm{KOH}$. (b) $\mathrm{HCO}_{3}{ }^{-}$and $\mathrm{CO}_{3}{ }^{2-}$ concentrations derived from the spectra in (a). (c) Fitted concentrations of $\mathrm{HCO}_{3}{ }^{-}, \mathrm{CO}_{3}{ }^{2-}, \mathrm{CO}_{2}(\mathrm{aq})$ and $\mathrm{OH}^{-}$and (d) $\mathrm{pH}$ profile with respect to distance from GDE surface. 
Note that the trends of concentration change for both $\mathrm{HCO}_{3}{ }^{-}$and $\mathrm{CO}_{3}{ }^{2-}$ are less well-defined in the region of $-40 \mu \mathrm{m}<\mathrm{x}<0 \mu \mathrm{m}$ (Figure $2 \mathrm{~b}$ ). We believe this is due to the poor spatial resolution of our Raman measurements in this region, which is much worse than the optimal micron level because: i) the laser beam is focused into liquid instead of on a substrate, ii) the electrolyte is flowing, and iii) there is likely interference from the nearby electrode. Therefore, the $\mathrm{HCO}_{3}{ }^{-}$and $\mathrm{CO}_{3}{ }^{2-}$ concentrations directly derived from the Raman spectra need to be corrected. We consider that in our system the region of interest can be treated as a quasi-one-dimensional channel (Figure 1b). Namely, the concentrations of the species of interest are dependent on $\mathrm{x}$ but are uniform along the $\mathrm{y}$ and $\mathrm{z}$ directions. ${ }^{28,34}$ The concentration of $\mathrm{HCO}_{3}{ }^{-}$ at any given position $\mathrm{x}$ is influenced by both acid-base reactions and diffusion:

$$
\frac{\partial \mathrm{c}_{1}}{\partial \mathrm{t}}=\mathrm{D}_{1} \frac{\partial^{2} \mathrm{c}_{1}}{\partial \mathrm{x}^{2}}+\mathrm{k}_{1 \mathrm{f}} \mathrm{c}_{3} \mathrm{c}_{4}-\mathrm{k}_{1 \mathrm{r}} \mathrm{c}_{1}-\mathrm{k}_{2 \mathrm{f}} \mathrm{c}_{1} \mathrm{c}_{3}+\mathrm{k}_{2 \mathrm{r}} \mathrm{c}_{2}
$$

where $\mathrm{c}_{1}, \mathrm{c}_{2}, \mathrm{c}_{3}$ and $\mathrm{c}_{4}$ are concentrations of $\mathrm{HCO}_{3}{ }^{-}, \mathrm{CO}_{3}{ }^{2-}, \mathrm{OH}^{-}$and $\mathrm{CO}_{2}(\mathrm{aq})$, respectively, $\mathrm{D}_{1}$ is the diffusion coefficient of $\mathrm{HCO}_{3}^{-}$, and $\mathrm{k}_{1 \mathrm{f}}, \mathrm{k}_{1 \mathrm{r}}, \mathrm{k}_{2 \mathrm{f}}$ and $\mathrm{k}_{2 \mathrm{r}}$ are the forward and reverse reaction rate constants of the following two reactions:

$$
\begin{aligned}
& \mathrm{CO}_{2}(\mathrm{aq})+\mathrm{OH}^{-} \rightleftharpoons \mathrm{HCO}_{3}{ }^{-} \\
& \mathrm{HCO}_{3}{ }^{-}+\mathrm{OH}^{-} \rightleftharpoons \mathrm{CO}_{3}{ }^{2-}+\mathrm{H}_{2} \mathrm{O}
\end{aligned}
$$

We assume Reactions (I) and (II) are at equilibrium, which means $\mathrm{k}_{1 \mathrm{f}} \mathrm{c}_{3} \mathrm{c}_{4}=\mathrm{k}_{1 \mathrm{r}} \mathrm{c}_{1}$ and $\mathrm{k}_{2 \mathrm{f}} \mathrm{c}_{1} \mathrm{c}_{3}=\mathrm{k}_{2 \mathrm{r}} \mathrm{c}_{2}$. In steady state, the concentration of $\mathrm{HCO}_{3}{ }^{-}$does not change over time, i.e. $\frac{\partial \mathrm{c}_{1}}{\partial \mathrm{t}}=0$. Equation (1) can therefore be simplified to $\frac{\partial^{2} c_{1}}{\partial \mathrm{x}^{2}}=0$, which suggests the concentration of $\mathrm{HCO}_{3}^{-}$should be linear with respect to $\mathrm{x}$. The same analysis applies to $\mathrm{CO}_{3}{ }^{2-}$ and $\mathrm{CO}_{2}$ (aq). Therefore, we used the $\mathrm{HCO}_{3}{ }^{-}$and $\mathrm{CO}_{3}{ }^{2-}$ concentration data measured in the region of $-120 \mu \mathrm{m} \leqslant \mathrm{x} \leqslant-40 \mu \mathrm{m}$ to fit linear functions of $\mathrm{x}$, because in this region they are reasonably linear with respect to $\mathrm{x}$ and the detection is not disrupted by the electrode. As shown in Figure 2c, in the region from $\mathrm{x}=-120 \mu \mathrm{m}$ to $\mathrm{x}=-26 \mu \mathrm{m}, \mathrm{HCO}_{3}{ }^{-}$and $\mathrm{CO}_{3}{ }^{2-}$ are dominant species, and the $\mathrm{HCO}_{3}{ }^{-}$concentration increases linearly with $\mathrm{x}$ from $0.022 \mathrm{M}$ to $0.18 \mathrm{M}$ while the $\mathrm{CO}_{3}{ }^{2-}$ concentration decreases linearly with $\mathrm{x}$ from $0.20 \mathrm{M}$ to $0.0012 \mathrm{M}$. In the region of $-26 \mu \mathrm{m} \leqslant \mathrm{x} \leqslant 0 \mu \mathrm{m}$, the concentration of $\mathrm{CO}_{3}{ }^{2-}$ approaches zero and the dominant species are $\mathrm{HCO}_{3}{ }^{-}$and $\mathrm{CO}_{2}$ (aq). The $\mathrm{HCO}_{3}{ }^{-}$ concentration increases from $0.18 \mathrm{M}$ at $\mathrm{x}=-26 \mu \mathrm{m}$ to $0.23 \mathrm{M}$ at $\mathrm{x}=0 \mu \mathrm{m}$, and the $\mathrm{CO}_{2}(\mathrm{aq})$ concentration increases from $0.0028 \mathrm{M}$ at $\mathrm{x}=-26 \mu \mathrm{m}$ to its saturated level at $\mathrm{x}=0 \mu \mathrm{m}$, i.e. $0.033 \mathrm{M} \cdot{ }^{35}$ As minor species, the concentrations of $\mathrm{CO}_{2}(\mathrm{aq})$ in the $-120 \mu \mathrm{m} \leqslant \mathrm{x} \leqslant-26 \mu \mathrm{m}$ region, $\mathrm{CO}_{3}{ }^{2-}$ in the $-26 \mu \mathrm{m} \leqslant \mathrm{x} \leqslant 0 \mu \mathrm{m}$ region, and $\mathrm{OH}^{-}$in the entire region can be calculated from the acid-base equilibria (Figure 2c). More detailed analysis and fitting results are available in the Supporting Information. As shown in Figure 2d, the $\mathrm{pH}$ profile for the $\mathrm{pH}$ gradient region can be divided into two regimes, one governed by the $\mathrm{CO}_{2} / \mathrm{HCO}_{3}{ }^{-}$ buffer pair and the other by $\mathrm{HCO}_{3}{ }^{-} / \mathrm{CO}_{3}{ }^{2-}$. At $\mathrm{x}=0 \mu \mathrm{m}$, i.e. the cathode/electrolyte interface, the $\mathrm{pH}$ is 7.2 , 
suggesting that the $\mathrm{KOH}$ electrolyte is almost completely neutralized by $\mathrm{CO}_{2}$. The $\mathrm{pH}$ increases to $>11$ at $\mathrm{x}=-120 \mu \mathrm{m}$, starting to approach that of the bulk electrolyte.

The foundation of our analysis is the assumption of acid-base equilibrium, which we made on the basis that the two neutralization reactions, i.e. Reactions (I) and (II), are fast with $\mathrm{k}_{1 \mathrm{f}}=5.93 \times 10^{3} \mathrm{M}^{-1} \mathrm{~s}^{-1}$ and $\mathrm{k}_{2 \mathrm{f}}=1$ $\times 10^{8} \mathrm{M}^{-1} \mathrm{~s}^{-1}$. To further confirm the validity of this assumption, we carried out two sets of experiments. We noticed that the total concentration of negative charges from $\mathrm{HCO}_{3}{ }^{-}$and $\mathrm{CO}_{3}{ }^{2-}$ in the scanned region is approximately $0.4 \mathrm{M}$ (Figure S2), significantly below the concentration of the starting $1 \mathrm{M} \mathrm{KOH}$ electrolyte. This raised a concern whether there is still a high concentration of $\mathrm{OH}^{-}$in this region. If so, Reactions (I) and (II) are not at equilibrium, which would violate our assumption. To examine this issue, we replaced the $1 \mathrm{M} \mathrm{KOH}$ electrolyte with a $\mathrm{N}\left(\mathrm{CH}_{3}\right)_{4} \mathrm{OH}$ electrolyte of the same concentration so that the cation concentration can be quantified by Raman spectroscopy (Figure S3 and S4). Under identical operating conditions, the $\mathrm{N}\left(\mathrm{CH}_{3}\right)_{4}{ }^{+}$concentration over $-110 \mu \mathrm{m} \leqslant \mathrm{x} \leqslant-10 \mu \mathrm{m}$ is found to be approximately $0.4 \mathrm{M}$ (Figure S5), in good agreement with the total charge concentration of $\mathrm{HCO}_{3}{ }^{-}$and $\mathrm{CO}_{3}{ }^{2-}$. Since charge neutrality always prevails, this result suggests that $\mathrm{OH}^{-}$is indeed a minor species in the $\mathrm{pH}$ gradient region and the acid-base equilibria hold. The electrolyte concentration in this region is significantly lower than that of the bulk because $\mathrm{OH}^{-}$is almost fully consumed by $\mathrm{CO}_{2}$ and the formed $\mathrm{HCO}_{3}{ }^{-}$and $\mathrm{CO}_{3}{ }^{2-}$ diffuse. As evidence, we found that the $\mathrm{N}\left(\mathrm{CH}_{3}\right)_{4}{ }^{+}$concentration is around $1 \mathrm{M}$ when $\mathrm{CO}_{2}$ is replaced with $\operatorname{Ar}($ Figure S6). In another experiment, we varied the flow rates of $\mathrm{CO}_{2}$ and $\mathrm{KOH}$ electrolyte independently. We first changed the $\mathrm{CO}_{2}$ gas flow rate between $5 \mathrm{sccm}$ and $25 \mathrm{sccm}$ at a fixed electrolyte flow rate of $0.5 \mathrm{~mL} / \mathrm{min}$. The result shows that at higher gas flow rates, more $\mathrm{CO}_{2}$ reacts with the electrolyte and the $\mathrm{pH}$ gradient region is wider. At $5 \mathrm{sccm}, \mathrm{HCO}_{3}{ }^{-}$is detectable till $\mathrm{x}=-70 \mu \mathrm{m}$; when the $\mathrm{CO}_{2}$ flow rate is increased to 25 sccm, $\mathrm{HCO}_{3}{ }^{-}$penetrates to $\mathrm{x}=-130 \mu \mathrm{m}$ (Figure S7). We also changed the electrolyte flow rate between $0.6 \mathrm{~mL} / \mathrm{min}$ and $0.1 \mathrm{~mL} / \mathrm{min}$ at a fixed $\mathrm{CO}_{2}$ flow rate of $20 \mathrm{sccm}$. The $\mathrm{pH}$ gradient region becomes wider at slower electrolyte flow rates (Figure S8). The responses of the $\mathrm{HCO}_{3}{ }^{-}$and $\mathrm{CO}_{3}{ }^{2-}$ concentration profiles to the gas and electrolyte flow rates again verify that our system is not limited by the kinetics of the acid-base reactions.

We then operated the electrochemical cell at constant-current $\mathrm{CO}_{2}$ reduction conditions and performed insitu Raman measurements to study the $\mathrm{pH}$ changes near the GDE surface. In the current density range studied, the catalyst, cobalt phthalocyanine molecules supported on carbon nanotubes (CoPc/CNT), converts $\mathrm{CO}_{2}$ to $\mathrm{CO}$ with high selectivity (Figure S9). ${ }^{1-2}$ The conversion of $\mathrm{CO}_{2}$ to $\mathrm{CO}$ consumes protons likely from $\mathrm{H}_{2} \mathrm{O}$ and thus generates $\mathrm{OH}^{-}$, which can counter the effect of $\mathrm{CO}_{2}-\mathrm{OH}^{-}$neutralization on the local $\mathrm{pH}$. At the current density of $50 \mathrm{~mA} / \mathrm{cm}^{2}$ (Figure $\mathrm{S} 10$ ), the $\mathrm{HCO}_{3}{ }^{-}$concentration near the cathode 
surface $(\mathrm{x}=-10 \mu \mathrm{m})$ is measured to be $0.23 \mathrm{M}$, which decreases to $0.029 \mathrm{M}$ at $\mathrm{x}=-80 \mu \mathrm{m}$, and the $\mathrm{CO}_{3}{ }^{2-}$ concentration increases from $0.07 \mathrm{M}$ at $\mathrm{x}=-10 \mu \mathrm{m}$ to $0.14 \mathrm{M}$ at $\mathrm{x}=-80 \mu \mathrm{m}$ (Figure 3a and S11). The region where $\mathrm{HCO}_{3}{ }^{-}$is detectable is $40 \mu \mathrm{m}$ narrower at $50 \mathrm{~mA} / \mathrm{cm}^{2}$ than that in the open-circuit scenario (Figure $2 b$ ). Fitting the experimentally measured $\mathrm{HCO}_{3}{ }^{-}$and $\mathrm{CO}_{3}{ }^{2-}$ concentrations as linear functions of $\mathrm{x}$ gives smooth concentration profiles (Figure $3 \mathrm{~b}$ ), from which the $\mathrm{pH}$ profile can be derived. As shown in Figure $3 \mathrm{c}$, the local $\mathrm{pH}$ at the electrode/electrolyte interface is 9.05 , much higher than that in the opencircuit scenario (Figure 2d), and the $\mathrm{HCO}_{3}{ }^{-}$region is about $86 \mu \mathrm{m}$. When the current density is increased to $100 \mathrm{~mA} / \mathrm{cm}^{2}$ (Figure S12), the $\mathrm{HCO}_{3}{ }^{-}$region further shrinks to $37 \mu \mathrm{m}$ (Figure 3d, e and S13) and the cathode surface $\mathrm{pH}$ is determined to be 9.8 (Figure $3 \mathrm{f}$ ). When the current density reaches $150 \mathrm{~mA} / \mathrm{cm}^{2}$ (Figure S14), only $\mathrm{CO}_{3}{ }^{2-}$ can be observed at $\mathrm{x}=-10 \mu \mathrm{m}$ (Figure $\mathrm{S} 15$ ), indicating a cathode surface $\mathrm{pH}$ higher than 12. These findings confirm that the electrochemical $\mathrm{CO}_{2}$ reduction reaction indeed produces $\mathrm{OH}^{-}$at the cathode surface $;^{1,5}$ however, the produced $\mathrm{OH}^{-}$cannot fully offset the $\mathrm{OH}^{-}$consumed by the chemical reaction with $\mathrm{CO}_{2}$ even at a high current density of $150 \mathrm{~mA} / \mathrm{cm}^{2}$. In fact, as long as the one-pass $\mathrm{CO}_{2}$ conversion is not $100 \%$, the unreacted $\mathrm{CO}_{2}$ will react with $\mathrm{KOH}$ at the interface.

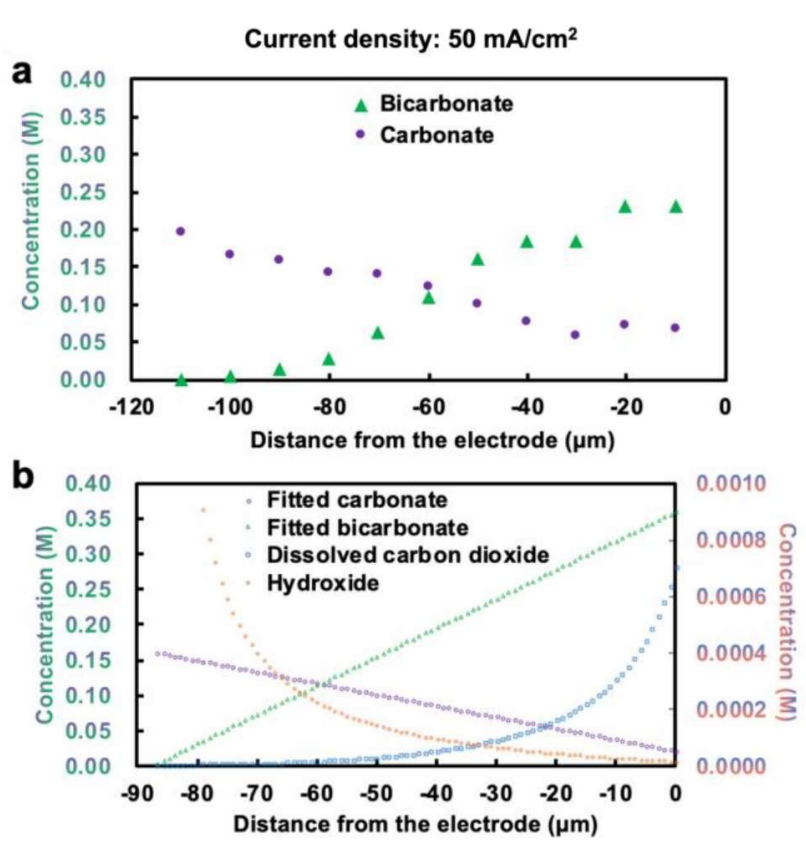

C

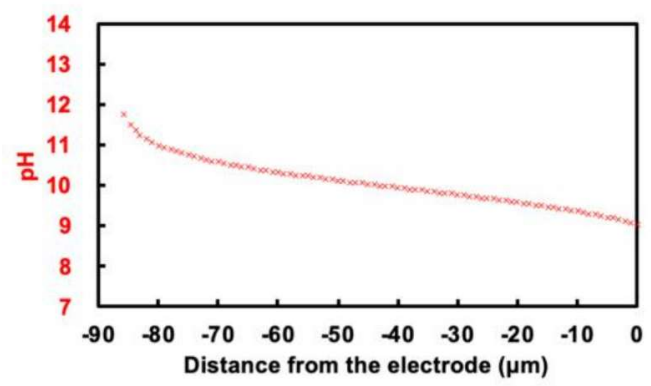

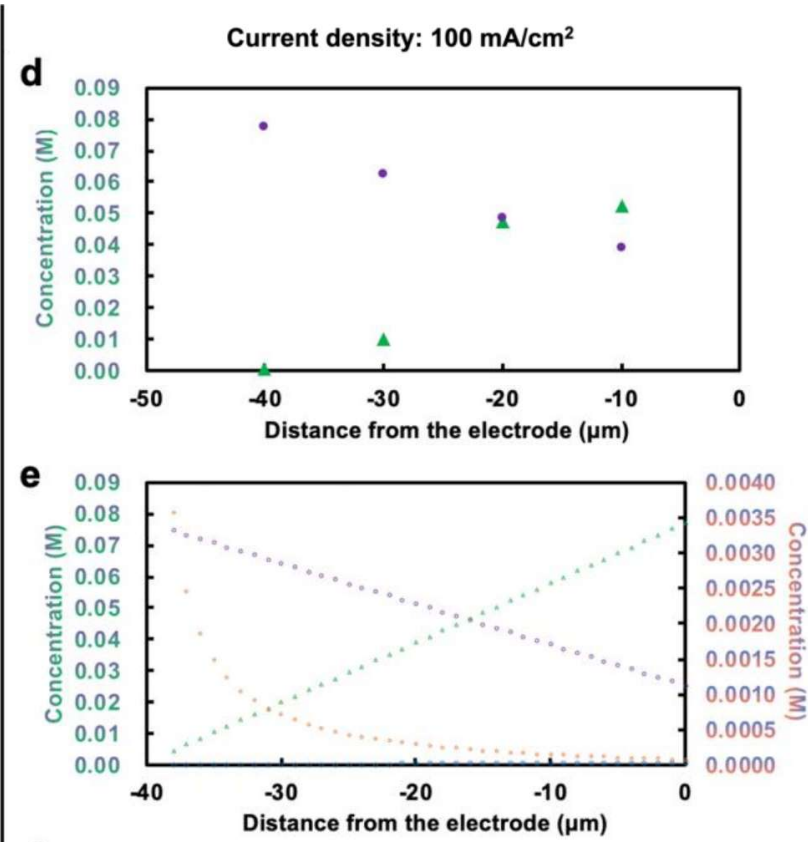

f

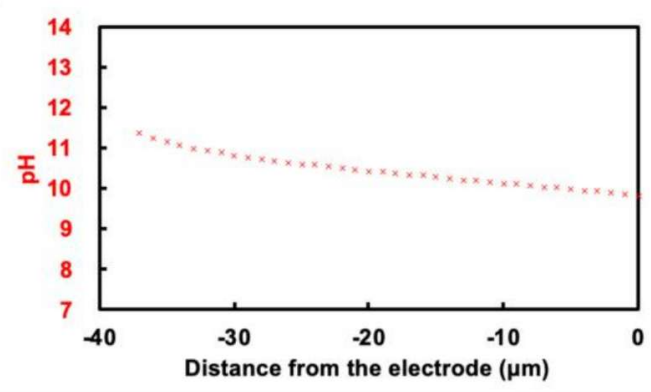


Figure 3. Measured $\mathrm{HCO}_{3}{ }^{-}$and $\mathrm{CO}_{3}{ }^{2-}$ concentrations with respect to distance from GDE surface at current densities of (a) $50 \mathrm{~mA} / \mathrm{cm}^{2}$ and (d) $100 \mathrm{~mA} / \mathrm{cm}^{2}$. Electrolyte: $1 \mathrm{M} \mathrm{KOH}$. (b) and (e): Fitted concentrations of $\mathrm{HCO}_{3}{ }^{-}, \mathrm{CO}_{3}{ }^{2-}, \mathrm{CO}_{2}(\mathrm{aq})$ and $\mathrm{OH}^{-}$corresponding to (a) and (d), respectively. (c) and (f): $\mathrm{pH}$ profiles derived from (b) and (e), respectively.

The acid-base reaction between $\mathrm{CO}_{2}$ and electrolyte occurs even when a $1 \mathrm{M} \mathrm{KHCO}_{3}$ aqueous solution is used as the electrolyte. As shown in Figure 4a, both $\mathrm{HCO}_{3}{ }^{-}$and $\mathrm{CO}_{3}{ }^{2-}$ are detected by Raman spectroscopy in the bulk of the $1 \mathrm{M} \mathrm{KHCO}_{3}$ electrolyte (purple highlight), whereas no $\mathrm{CO}_{3}{ }^{2-}$ signal is found near the cathode surface in the region of $-120 \mu \mathrm{m} \leqslant \mathrm{x} \leqslant-10 \mu \mathrm{m}$. This is strong evidence that the $\mathrm{CO}_{2}$ gas reacts with the $\mathrm{CO}_{3}{ }^{2-}$ in the electrolyte to form $\mathrm{HCO}_{3}{ }^{-}$. When the electrochemical $\mathrm{CO}_{2}$ reduction reaction proceeds at $50 \mathrm{~mA} / \mathrm{cm}^{2}$ (Figure $\mathrm{S} 16$ ), both $\mathrm{HCO}_{3}{ }^{-}$and $\mathrm{CO}_{3}{ }^{2-}$ are present in the region of $-130 \mu \mathrm{m} \leqslant \mathrm{x} \leqslant-10 \mu \mathrm{m}$. The $\mathrm{CO}_{3}{ }^{2-}$ concentration drops from $0.61 \mathrm{M}$ at $\mathrm{x}=-10 \mu \mathrm{m}$ to $0.18 \mathrm{M}$ at $\mathrm{x}=-130 \mu \mathrm{m}$, while the $\mathrm{HCO}_{3}{ }^{-}$ concentration increases from $0.11 \mathrm{M}$ at $\mathrm{x}=-10 \mu \mathrm{m}$ to $1.26 \mathrm{M}$ at $\mathrm{x}=-130 \mu \mathrm{m}$ (Figure $4 \mathrm{~b}$ ). Fitting these measured concentrations into linear functions of $\mathrm{x}$ gives concentration and $\mathrm{pH}$ profiles (Figure $4 \mathrm{c}, \mathrm{d}$ ), which show that the local $\mathrm{pH}$ near the cathode surface is 11.9 , much higher than that of the electrolyte bulk. Note that under these conditions, $\mathrm{CO}_{2}$ will still chemically react with the electrolyte, and the reaction rate would be even faster than that in the zero-current scenario because the local $\mathrm{pH}$ is now higher. However, the $\mathrm{CO}_{2-}$ electrolyte neutralization reaction is not significant enough to balance the $\mathrm{OH}^{-}$generated from the electrochemical $\mathrm{CO}_{2}$ reduction reaction, which is the driving force of the basic local $\mathrm{pH}$.

a
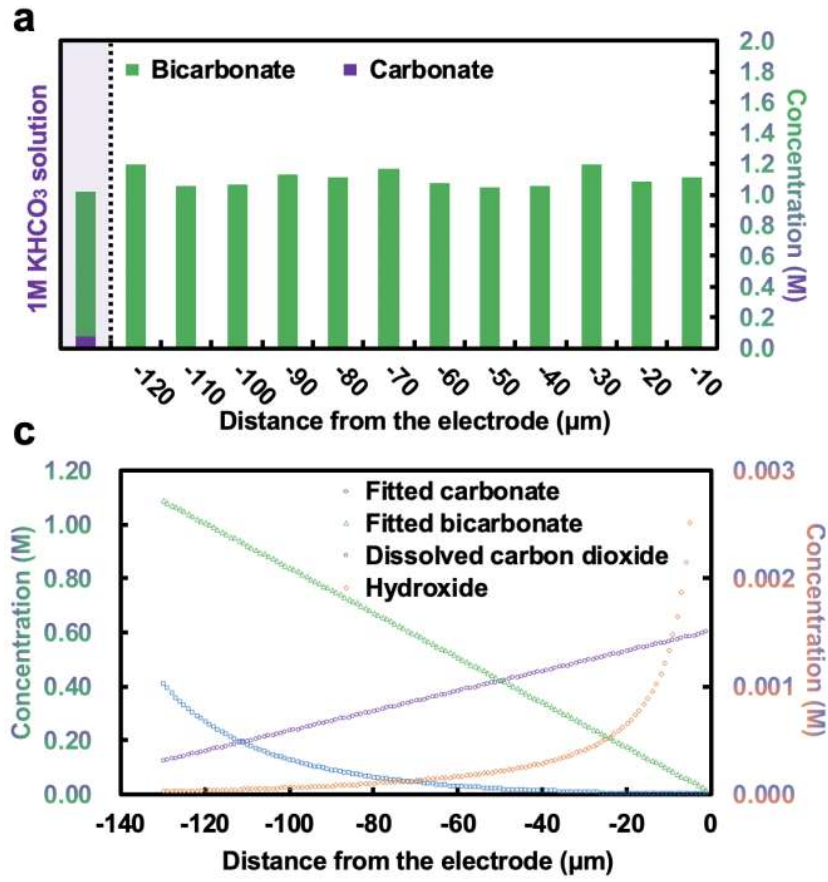
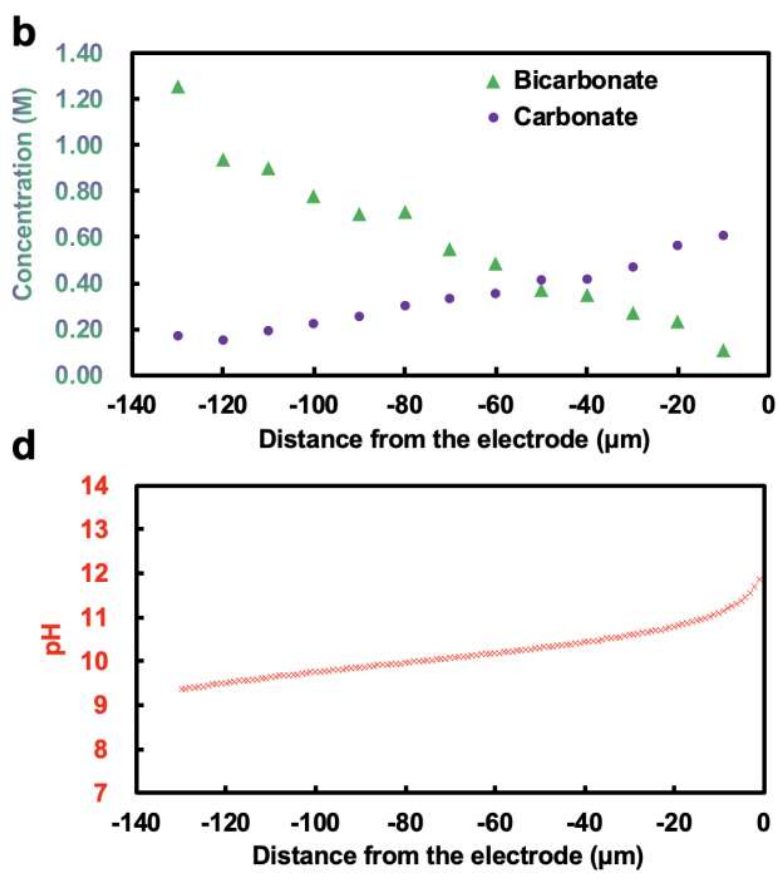
Figure 4. Measured $\mathrm{HCO}_{3}{ }^{-}$and $\mathrm{CO}_{3}{ }^{2-}$ concentrations with respect to distance from GDE surface at current densities of (a) $0 \mathrm{~mA} / \mathrm{cm}^{2}$ and (b) $50 \mathrm{~mA} / \mathrm{cm}^{2}$. Electrolyte: $1 \mathrm{M} \mathrm{KHCO}_{3}$. (c) Fitted concentrations of $\mathrm{HCO}_{3}{ }^{-}$, $\mathrm{CO}_{3}{ }^{2-}, \mathrm{CO}_{2}$ (aq) and $\mathrm{OH}^{-}$and (d) $\mathrm{pH}$ profile with respect to distance from GDE surface.

\section{Conclusion}

In conclusion, we have demonstrated that in-situ micro-area Raman spectroscopy is an effective tool for studying the local $\mathrm{pH}$ near $\mathrm{CO}_{2}$ reduction GDEs under working conditions. Applying this technique, we have obtained experimental evidence that $\mathrm{CO}_{2}$ chemically reacts with alkaline electrolyte at the interface. This neutralization reaction has significant influences on the local $\mathrm{pH}$ and the electrochemical performance. This continuous-flow Raman electrochemical cell could also be applicable to other reaction systems involving GDEs. The spatial resolution and Raman sensitivity might be limitations, which could be overcome by techniques such as surface enhancement.

\section{Acknowledgement}

This work was supported by the National Science Foundation (Grant CHE-1651717). X.L. acknowledges the Croucher Fellowship for Postdoctoral Research. J.S.F acknowledges support from the National Science Foundation (Grant CHE-1665324). H.W. acknowledges support from the Sloan Research Fellowship. The authors thank Dr. Yifei Wang (Department of Mechanical Engineering, University of Hong Kong) for assistance with cell fabrication.

\section{Supporting Information}

Experimental details, concentration profile fitting and supplementary figures.

\section{Reference}

1. Lu, X.; Wu, Y.; Yuan, X.; Huang, L.; Wu, Z.; Xuan, J.; Wang, Y.; Wang, H., High-performance electrochemical $\mathrm{CO}_{2}$ reduction cells based on non-noble metal catalysts. ACS Energy Letters 2018, 3 (10), 2527-2532.

2. Zhang, X.; Wu, Z.; Zhang, X.; Li, L.; Li, Y.; Xu, H.; Li, X.; Yu, X.; Zhang, Z.; Liang, Y.; Wang, H., Highly selective and active $\mathrm{CO}_{2}$ reduction electrocatalysts based on cobalt phthalocyanine/carbon nanotube hybrid structures. Nature Communications 2017, 8, 14675.

3. Wang, M.; Torbensen, K.; Salvatore, D.; Ren, S.; Joulié, D.; Dumoulin, F.; Mendoza, D.; Lassalle Kaiser, B.; Işci, U.; Berlinguette, C. P.; Robert, M., $\mathrm{CO}_{2}$ electrochemical catalytic reduction with a highly active cobalt phthalocyanine. Nature Communications 2019, 10, 3602. 
4. Salvatore, D. A.; Weekes, D. M.; He, J.; Dettelbach, K. E.; Li, Y. C.; Mallouk, T. E.; Berlinguette, C. P., Electrolysis of gaseous $\mathrm{CO}_{2}$ to $\mathrm{CO}$ in a flow cell with a bipolar membrane. ACS Energy Letters 2017, $3(1), 149-154$.

5. Verma, S.; Hamasaki, Y.; Kim, C.; Huang, W.; Lu, S.; Jhong, H. R. M.; Gewirth, A. A.; Fujigaya, T.; Nakashima, N.; Kenis, P. J., Insights into the low overpotential electroreduction of $\mathrm{CO}_{2}$ to $\mathrm{CO}$ on a supported gold catalyst in an alkaline flow electrolyzer. ACS Energy Letters 2017, 3 (1), 193-198.

6. Lu, X.; Wu, Y.; Yuan, X.; Wang, H., An integrated $\mathrm{CO}_{2}$ electrolyzer and formate fuel cell enabled by a reversibly restructuring $\mathrm{Pb}-\mathrm{Pd}$ bimetallic catalyst. Angewandte Chemie International Edition 2019, $58(12), 4031-4035$.

7. Gao, D.; Zhou, H.; Cai, F.; Wang, D.; Hu, Y.; Jiang, B.; Cai, W. B.; Chen, X.; Si, R.; Yang, F.; Miao, S.; Wang, J.; Wang, G.; Bao, X., Switchable $\mathrm{CO}_{2}$ electroreduction via engineering active phases of Pd nanoparticles. Nano Research 2017, 10, 2181-2191.

8. Zheng, Y.; Vasileff, A.; Zhou, X.; Jiao, Y.; Jaroniec, M.; Qiao, S. Z., Understanding the roadmap for electrochemical reduction of $\mathrm{CO}_{2}$ to multi-carbon oxygenates and hydrocarbons on copper-based catalysts. Journal of the American Chemical Society 2019, 141 (19), 7646-7659.

9. Ma, M.; Djanashvili, K.; Smith, W. A., Controllable hydrocarbon formation from the electrochemical reduction of $\mathrm{CO}_{2}$ over $\mathrm{Cu}$ nanowire arrays. Angewandte Chemie International Edition 2016, 55 (23), 6680-6684.

10. Weng, Z.; Wu, Y.; Wang, M.; Jiang, J.; Yang, K.; Huo, S.; Wang, X. F.; Ma, Q.; Brudvig, G. W.; Batista, V. S.; Liang, Y.; Feng, Z.; Wang, H., Active sites of copper-complex catalytic materials for electrochemical carbon dioxide reduction. Nature Communications 2018, 9, 415.

11. Dinh, C. T.; Burdyny, T.; Kibria, M. G.; Seifitokaldani, A.; Gabardo, C. M.; de Arquer, F. P. G.; Kiani, A.; Edwards, J. P.; De Luna, P.; Bushuyev, O. S.; Zhou, C.; Quintero-Bermudez, R.; Pang, Y.; Sinton, D.; Sargent, E. H., $\mathrm{CO}_{2}$ electroreduction to ethylene via hydroxide-mediated copper catalysis at an abrupt interface. Science 2018, 360 (6390), 783-787.

12. Wu, Y.; Jiang, Z.; Lu, X.; Liang, Y.; Wang, H., Domino electroreduction of $\mathrm{CO}_{2}$ to methanol on a molecular catalyst. Nature 2019, 575, 639-642.

13. Li, F.; Li, Y. C.; Wang, Z.; Li, J.; Nam, D. H.; Lum, Y.; Luo, M.; Wang, X.; Ozden, A.; Hung, S. F.; Chen, B.; Wang, Y.; Wicks, J.; Xu, Y.; Li, Y.; Gabardo, C. M.; Dinh, C. T.; Wang, Y.; Zhuang, T. T.; Sinton, D.; Sargent, E. H., Cooperative $\mathrm{CO}_{2}$-to-ethanol conversion via enriched intermediates at molecule-metal catalyst interfaces. Nature Catalysis 2020, 3, 75-82.

14. Lv, J. J.; Jouny, M.; Luc, W.; Zhu, W.; Zhu, J. J.; Jiao, F., A highly porous copper electrocatalyst for carbon dioxide reduction. Advanced Materials 2018, 30 (49), 1803111. 
15. Clark, E. L.; Resasco, J.; Landers, A.; Lin, J.; Chung, L. T.; Walton, A.; Hahn, C.; Jaramillo, T. F.; Bell, A. T., Standards and protocols for data acquisition and reporting for studies of the electrochemical reduction of carbon dioxide. ACS Catalysis 2018, 8 (7), 6560-6570.

16. Cindrella, L.; Kannan, A. M.; Lin, J.; Saminathan, K.; Ho, Y.; Lin, C.; Wertz, J., Gas diffusion layer for proton exchange membrane fuel cells - A review. Journal of Power Sources 2009, 194 (1), 146160.

17. Liu, K.; Smith, W. A.; Burdyny, T., Introductory guide to assembling and operating gas diffusion electrodes for electrochemical $\mathrm{CO}_{2}$ reduction. ACS Energy Letters 2019, 4 (3), 639-643.

18. Lu, X.; Jiang, Z.; Yuan, X.; Wu, Y.; Malpass Evans, R.; Zhong, Y.; Liang, Y.; McKeown, N. B.; Wang, $\mathrm{H}$., A bio-inspired $\mathrm{O}_{2}$-tolerant catalytic $\mathrm{CO}_{2}$ reduction electrode. Science Bulletin 2019, 64 (24), 1890 1895.

19. Gu, J.; Hsu, C.-S.; Bai, L.; Chen, H. M.; Hu, X., Atomically dispersed $\mathrm{Fe}^{3+}$ sites catalyze efficient $\mathrm{CO}_{2}$ electroreduction to CO. Science 2019, 364 (6445), 1091-1094.

20. Loiudice, A.; Lobaccaro, P.; Kamali, E. A.; Thao, T.; Huang, B. H.; Ager, J. W.; Buonsanti, R., Tailoring copper nanocrystals towards $\mathrm{C} 2$ products in electrochemical $\mathrm{CO}_{2}$ reduction. Angewandte Chemie International Edition 2016, 55 (19), 5789-5792.

21. de Arquer, F. P. G.; Dinh, C. T.; Ozden, A.; Wicks, J.; McCallum, C.; Kirmani, A. R.; Nam, D. H.; Gabardo, C.; Seifitokaldani, A.; Wang, X.; Li, Y. C.; Li, F.; Edwards, J.; Richter, L. J.; Thorpe, S. J.; Sinton, D.; Sargent, E. H., $\mathrm{CO}_{2}$ electrolysis to multicarbon products at activities greater than $1 \mathrm{~A} \mathrm{~cm}^{-2}$. Science 2020, 367 (6478), 661-666.

22. Ma, W.; Xie, S.; Liu, T.; Fan, Q.; Ye, J.; Sun, F.; Jiang, Z.; Zhang, Q.; Cheng, J.; Wang, Y., Electrocatalytic reduction of $\mathrm{CO}_{2}$ to ethylene and ethanol through hydrogen-assisted $\mathrm{C}-\mathrm{C}$ coupling over fluorine-modified copper. Nature Catalysis 2020, 3, 478-487.

23. Gupta, N.; Gattrell, M.; MacDougall, B., Calculation for the cathode surface concentrations in the electrochemical reduction of $\mathrm{CO}_{2}$ in $\mathrm{KHCO}_{3}$ solutions. Journal of Applied Electrochemistry 2006, 36, 161-172.

24. Honda, T.; Murase, K.; Hirato, T.; Awakura, Y., pH measurement in the vicinity of a cathode evolving hydrogen gas using an antimony microelectrode. Journal of Applied Electrochemistry 1998, 28, 617622.

25. Wolfe, R. C.; Weil, K. G.; Shaw, B. A.; Pickering, H. W., Measurement of $\mathrm{pH}$ gradients in the crevice corrosion of iron using a palladium hydride microelectrode. Journal of the Electrochemical Society 2005, 152 (2), B82-B88.

26. Morris, C. A.; Chen, C. C.; Ito, T.; Baker, L. A., Local pH measurement with scanning ion conductance microscopy. Journal of The Electrochemical Society 2013, 160 (8), H430-H435. 
27. Henstridge, M. C.; Wildgoose, G. G.; Compton, R. G., Generator-collector experiments at a single electrode: Exploring the general applicability of this approach by comparing the performance of surface immobilized versus solution phase sensing molecules. Langmuir 2010, 26 (2), 1340-1346.

28. Auinger, M.; Katsounaros, I.; Meier, J. C.; Klemm, S. O.; Biedermann, P. U.; Topalov, A. A.; Rohwerder, M.; Mayrhofer, K. J., Near-surface ion distribution and buffer effects during electrochemical reactions. Physical Chemistry Chemical Physics 2011, 13, 16384-16394.

29. Katsounaros, I.; Meier, J. C.; Klemm, S. O.; Topalov, A. A.; Biedermann, P. U.; Auinger, M.; Mayrhofer, K. J., The effective surface $\mathrm{pH}$ during reactions at the solid-liquid interface. Electrochemistry Communications 2011, 13 (6), 634-637.

30. Cannan, S.; Macklam, I. D.; Unwin, P. R., Three-dimensional imaging of proton gradients at microelectrode surfaces using confocal laser scanning microscopy. Electrochemistry Communications 2002, 4 (11), 886-892.

31. Rudd, N. C.; Cannan, S.; Bitziou, E.; Ciani, I.; Whitworth, A. L.; Unwin, P. R., Fluorescence confocal laser scanning microscopy as a probe of $\mathrm{pH}$ gradients in electrode reactions and surface activity. Analytical Chemistry 2005, 77 (19), 6205-6217.

32. Jiang, S.; Klingan, K.; Pasquini, C.; Dau, H., New aspects of operando Raman spectroscopy applied to electrochemical $\mathrm{CO}_{2}$ reduction on $\mathrm{Cu}$ foams. The Journal of Chemical Physics 2019, 150, 041718.

33. Yang, K.; Kas, R.; Smith, W. A., In situ infrared spectroscopy reveals persistent alkalinity near electrode surfaces during $\mathrm{CO}_{2}$ electroreduction. Journal of the American Chemical Society 2019, 141 (40), 15891-15900.

34. Carneiro Neto, E. B.; Lopes, M. C.; Pereira, E. C., Simulation of interfacial pH changes during hydrogen evolution reaction. Journal of Electroanalytical Chemistry 2016, 765, 92-99.

35. Li, T.; Lees, E. W.; Goldman, M.; Salvatore, D. A.; Weekes, D. M.; Berlinguette, C. P., Electrolytic conversion of bicarbonate into CO in a flow cell. Joule 2019, 3 (6), 1487-1497. 